\title{
Catalytic oxidation of anilines into azoxybenzenes on mesoporous silicas containing cobalt oxide
}

\author{
Ching-Fu Chang, Shiuh-Tzung Liu* \\ Department of Chemistry, National Taiwan University, Taipei 106, Taiwan, ROC
}

\section{A R T I C L E I N F O}

\section{Article history:}

Received 26 March 2008

Received in revised form 19 October 2008

Accepted 20 October 2008

Available online 30 October 2008

Keywords:

Oxidation

Azoxybenzenes

Cobalt oxide

Catalysis

\begin{abstract}
A B S T R A C T
Synthesis of cobalt-bound copolymers and the use of this polymer as a template to prepare mesoporous silicas containing cobalt oxide are reported. This material catalyzed the oxidation of anilines into the corresponding azoxybenzene efficiently with the hydrogen peroxide as the oxidant. Furthermore, the catalyst can be recycled without losing the activity.
\end{abstract}

(C) 2008 Elsevier B.V. All rights reserved.

\section{Introduction}

Azoxybenzene and its derivatives represent a new class of compounds displaying a broad range of potential application in materials because they have characteristic features emerging from the conjugated systems and polar functionality [1]. In addition, this type of compounds is the precursor for Wallach rearrangement, which offers a simple way to prepare hydroxyazobenzenes $[1 \mathrm{a}, 2]$. Generally, the preparation of azoxybenzenes is via the direct oxidation of the corresponding azobenzene (Eq. (1)) and many oxidizing agents such as hydrogen peroxide [3], dimethyldioxirane [4], sodium perborate [5] and peracid [6] have been used for this process. In the use of $\mathrm{H}_{2} \mathrm{O}_{2}$, Murray and coworkers found that the metal complex $\left(\mathrm{MeReO}_{3}\right)$ accelerated the oxidation to provide excellent yields of azoxybenzenes [3].<smiles>[Y]c1ccc(N=Nc2ccc([N+]([O-])=Nc3ccc([Y])cc3)cc2)cc1</smiles>

Azoxybenzene is known to be the intermediate from the oxidation of aniline or the reduction of nitroarene via the condensation of nitrosobenzene with $N$-phenylhydroxyamine. The oxidation steps of aniline leading to nitrobenzene are quite complex and a generally accepted mechanistic pathway is depicted in Scheme 1 [7]. Thus, manipulation of reaction conditions leading to the azoxy compound as a single product becomes a research interest for chemists. Till now, a few catalytic systems developed for this purpose have been reported [8-10]. Typically, these are perfluoroketone-silicate [8], polyoxometalate of a sandwich type structure [9] and titanium silicalite-1 (TS-1) [10]. Continuing our research on catalysis, we have developed a preparation of cobalt-containing mesoporous silica, which is active for the conversion of anilines into azoxybenzenes.

\section{Results and discussion}

\subsection{Preparation of catalyst}

* Corresponding author. Tel.: +8862 2366 0352; fax: +886223636359.

E-mail address: stliu@ntu.edu.tw(S.-T. Liu).

The cobalt-containing silicas (denoted as Si-Co) were synthesized through the condensation of tetraethoxysilane templated 


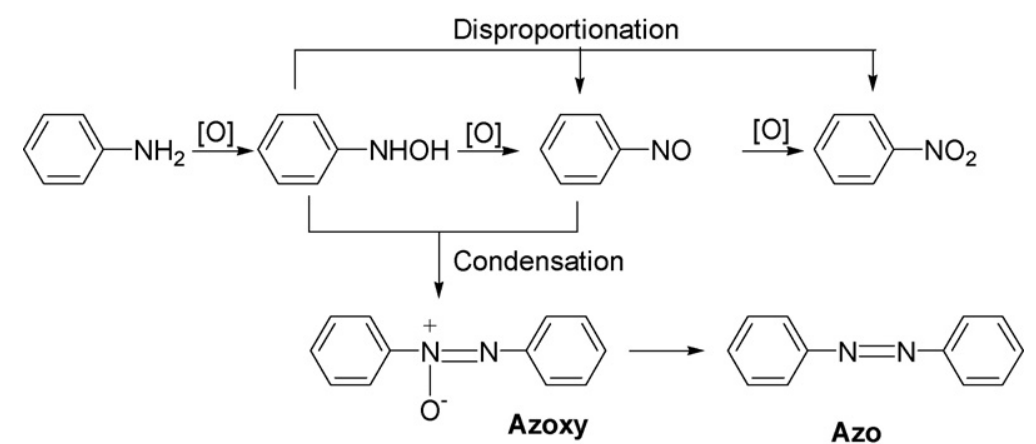

Scheme 1. Mechanistic pathway for oxidation of aniline.

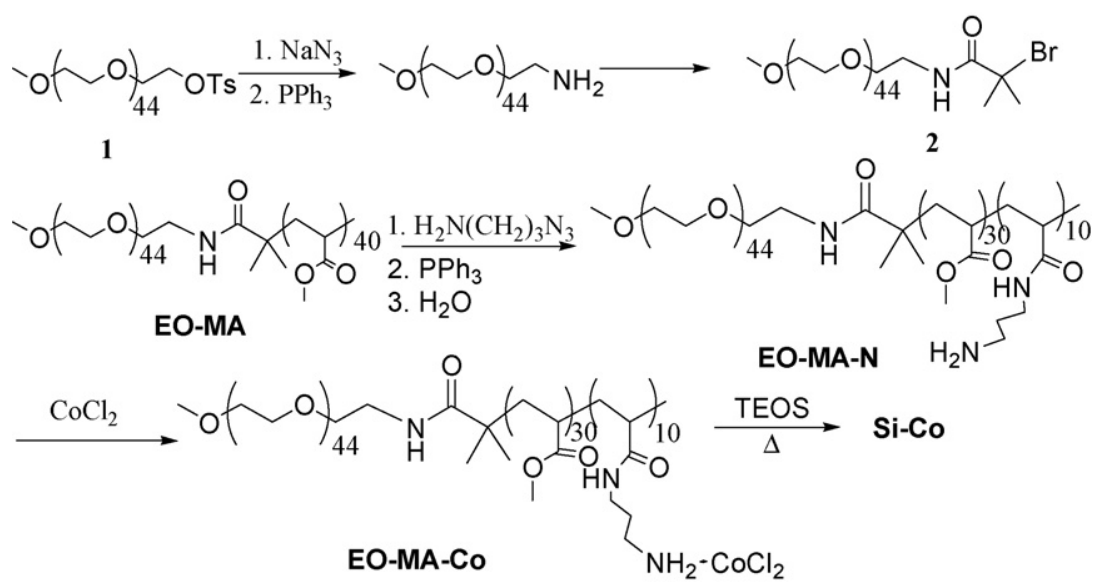

Scheme 2. Preparation of the metal-containing diblock copolymer.

by the amphiphilic diblock (EO-MA-Co) copolymer under acidic conditions [11]. Starting with the tosylate of the methylcapped polyethylene oxide $\mathrm{Me}\left(\mathrm{OCH}_{2} \mathrm{CH}_{2}\right)_{45} \mathrm{OTs}(\mathbf{1})$, the tosylate function was transformed into an amine function, which subsequently reacted with 2-bromoisobutyric chloride to provide the macro-initiator poly(ethylene oxide)-2-bromoisobutyrate (2) (Scheme 2). The formation of the amide linkage is required for keeping the copolymer intact during the further transformation of the diblock copolymers. A simple ester linkage formed from $\mathrm{Me}\left(\mathrm{OCH}_{2} \mathrm{CH}_{2}\right)_{45} \mathrm{OH}$ and 2-bromoisobutyric chloride would undergo hydrolysis during the reactions. Compound 2 was subjected to connection with the poly(methyl acrylate) chain by the atom transfer radical polymerization method [12]. In a typical run, the reaction of macro-initiator $(3.3 \mathrm{mmol})$ and methyl acrylate (MA) $(55 \mathrm{mmol})$ at $30^{\circ} \mathrm{C}$ for $10 \mathrm{~min}$ resulted in the formation of the desired EO-MA of $M_{N}=4500$ (PDI =1.14). Based on the GPC and ${ }^{1} \mathrm{H}$ NMR integration, the polymerization degree of MA is in an average of 40 units. Treatment of the diblock copolymer with 3aminopropyl azide provided the copolymer with the amido-linked side chain. The composition of the resulting modified copolymer (EO-MA-N), determined by ${ }^{1} \mathrm{H}$ NMR integration, included a 0.25 mole fraction of the azido group. Under anhydrous conditions, the copolymer reacted with triphenylphosphine to generate the iminophosphorane functionality [11,13], which was subsequently hydrolyzed to generate the amine function. Addition of $\mathrm{CoCl}_{2}$ to an aqueous solution of the copolymer readily caused the color change from purple into blue, indicating the formation of its metal complex (EO-MA-Co).

By using the metal-bound diblock copolymer EO-MA-Co as the template, preparation of the desired materials under acidic conditions was achieved. Upon calcination at $560^{\circ} \mathrm{C}$, the porous silica Si-Co was obtained. X-ray diffraction patterns of the sample show that the mesophase of the resulting porous silica is disordered. However, nitrogen absorption-desorption isotherms (Fig. 1) showed that the pore dimension of Si-Co is $13.3 \mathrm{~nm}$ with surface area of $499 \mathrm{~m}^{2} / \mathrm{g}$, typical of mesoporous materials and similar to those of related materials [11]. The content of cobalt species inside of channels was estimated to be $16.5 \mathrm{mg} / \mathrm{g}$ of silica via the analysis of ICP-mass determination. XPS analysis was carried out in order to determine the valence state of the cobalt species on silicas. The $\mathrm{O} 1 \mathrm{~s}$ XPS peak at $531.8 \mathrm{eV}$ was attributed mainly to the silicates. A detailed scan of the Co $2 \mathrm{p}_{3 / 2}$ area showed a peak at $783.3 \mathrm{eV}$, which is assigned to the binding-energy component of the cobalt oxide

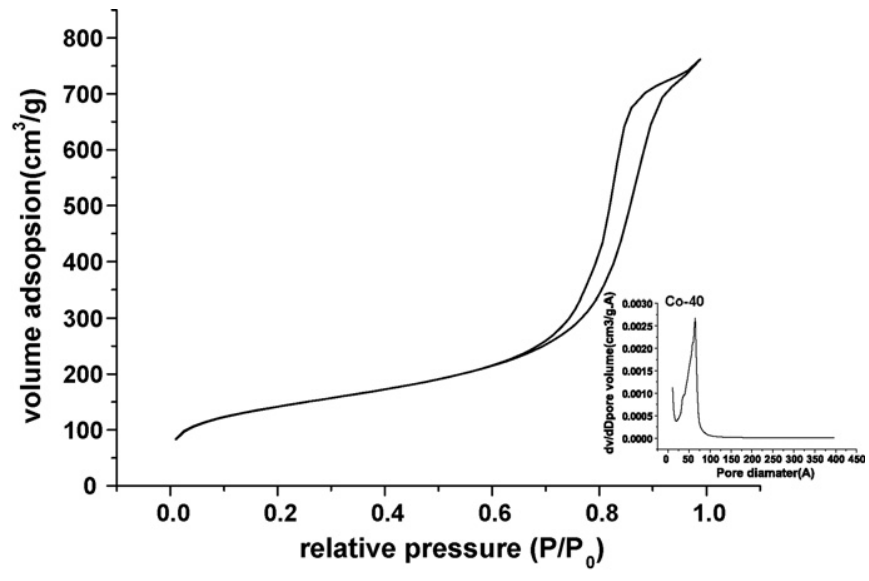

Fig. 1. Nitrogen absorption-desorption of Si-Co. 


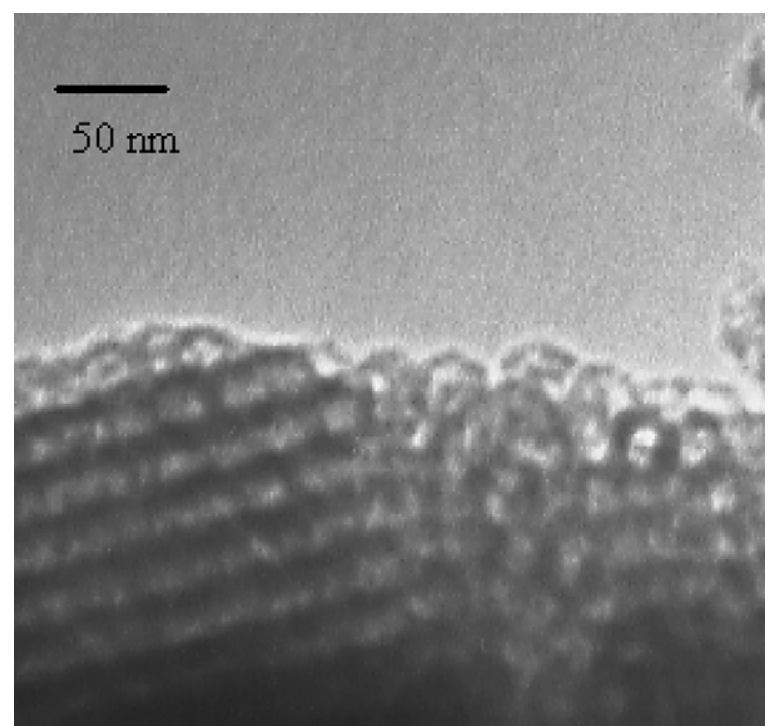

Fig. 2. SEM image of Si-Co.

(CoO). This value is consistent with the related species on metal oxide surface [14].

Fig. 2 shows the scanning electron microscopy (SEM) images of the prepared silicas. It was observed clearly that spherical morphology predominated in Si-Co. They were uniform in size and the average size of the spheres was around $20 \mathrm{~nm}$. Furthermore, no agglomeration of cobalt oxide could be observed on the surface of mesoporous silicas, suggesting a well-dispersed manner of the metal complex.

\subsection{Catalysis}

Oxidation of anilines with hydrogen peroxide over $\mathrm{Si}$-Co was investigated. The oxidation of aniline served as a model reaction (Eq. (2)) for studying the influence of catalysts and critical reaction parameters such as solvent, oxidant and temperature. Results are summarized in Table 1.

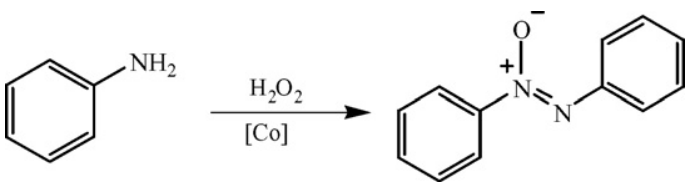

When hydrogen peroxide $(10 \mathrm{mmol})$ was added to a solution of aniline $(5 \mathrm{mmol})$ and Si-Co in acetonitrile $(1 \mathrm{~mL})$ under air atmosphere at $25^{\circ} \mathrm{C}$, azoxybenzene was obtained in $26 \%$ by GC analysis (entry 1 ). While optimizing the reaction conditions, we found that the yield of the desired product increased by increasing the amount of $\mathrm{H}_{2} \mathrm{O}_{2}$ (entries 2 and 3). However, the use of excess of reagents does not meet the economy of chemical reactions. This can be solved by raising the reaction temperature. Thus the yield reached to $78 \%$ at $55^{\circ} \mathrm{C}$, and $98 \%$ at $80^{\circ} \mathrm{C}$. Running the reaction without $\mathrm{Si}-\mathrm{Co}$ or with the use of a simple porous silica (SBA-15) with $\mathrm{CoCl}_{2}$ gave no desired product or poor yields (entries 6-8), indicating the necessity of the porous catalyst Si-Co.

As for the solvent effect, both water and acetonitrile are good choices. Providing the excellent yield in aqueous solution of this oxidation does meet the context of green chemistry. However, running in an aqueous medium gave also a trace amount of azobenzene as the side product at a higher reaction temperature (entry 15).

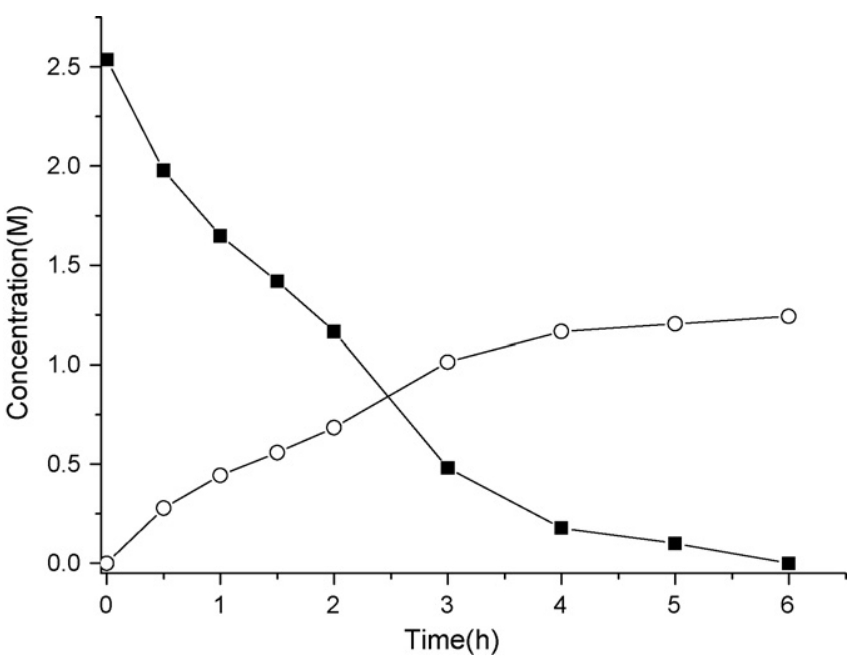

Fig. 3. Reaction profile for the oxidation of aniline at $80^{\circ} \mathrm{C}$ in the presence of $\mathrm{Si}-\mathrm{Co}$ : (○) azoxybenzene and ( $\mathbf{\square})$ aniline.

The production rate of azoxybenzene in the oxidation of aniline was also studied (Fig. 3). As shown in the diagram, there was no induction period for this catalyst. It appears that the conversion was fast with more than $80 \%$ conversion after $3 \mathrm{~h}$. From this reaction profile, the ratio of the reactant disappearance versus the product formation almost kept constant (2:1). There was no other side product found in this reaction, indicating that the intermediate in this oxidation step was readily converted into the product.

In view of the above results, the catalytic system that renders the best yield in oxidation of aniline into azoxybenzene was applied in the subsequent studies. Various substituted anilines were tested under this reaction conditions and the results are summarized in Table 2. When allowed to react with $\mathrm{H}_{2} \mathrm{O}_{2}$ via the Si-Co catalyst, substituted anilines afforded the corresponding azoxybenzene in excellent yields. $p$-Phenylenediamine did undergo coupling to yield a black material, which was presumably polymers (entry 1). It appears that the electronic effect of substituents had little influence on the production of the corresponding azoxybenzene. However, the steric effect of the substituents did affect the reaction. Oxidation of 2,4,6-trimethylaniline offered azoxymesitylene in $92 \%$ yield, but the 2,6-diisopropylaniline gave essentially no desired product (entry 4 versus entry 8 ). This indicates that the catalytic center is sensitive toward the sterically bulkiness of the substrates.

Finally, the stability and activity of the catalyst was tested in the recycle-use experiments. Typically, a mixture of aniline ( $5 \mathrm{mmol})$, Si-Co $(5 \mathrm{mg})$ and $\mathrm{H}_{2} \mathrm{O}_{2}(10 \mathrm{mmol})$ in acetonitrile $(1 \mathrm{~mL})$ was heated to $80^{\circ} \mathrm{C}$ for $8 \mathrm{~h}$. The mixture was filtered and the catalyst was washed twice with acetone, dried and reused in the further reaction. Over a period of three reaction cycles under the same conditions, no significant loss of activity was observed and the yield for each run was 98\%, 97\% and 95\%, respectively.

In summary, the procedure in this work offers several advantages for the preparation of azoxybenzenes from the corresponding aniline such as low loading of catalyst, mild conditions, high yields, and clean reactions, which make it a useful and attractive methodology for organic synthesis. The simple workup procedure is also beneficial to this method. Although the preparation of the catalyst was nontrivial, it offers information for the future design of new catalysts. Further applications of this catalyst to other transformations are currently under investigation. 
Table 1

Results of the oxidation of aniline with $\mathrm{H}_{2} \mathrm{O}_{2}$ in the presence of $\mathrm{Si}-\mathrm{Co}^{\mathrm{a}}$.

\begin{tabular}{|c|c|c|c|c|c|c|c|}
\hline Entry & Catalyst & Oxidant & Solvent & $T\left({ }^{\circ} \mathrm{C}\right)$ & $t(\mathrm{~h})$ & Conv. $^{\mathrm{b}}$ & Yield $^{c}$ \\
\hline 1 & $\mathrm{Si}-\mathrm{Co}$ & $\mathrm{H}_{2} \mathrm{O}_{2}(10 \mathrm{mmol})$ & $\mathrm{CH}_{3} \mathrm{CN}$ & 25 & 8 & 26 & 26 \\
\hline 2 & $\mathrm{Si}-\mathrm{Co}$ & $\mathrm{H}_{2} \mathrm{O}_{2}(20 \mathrm{mmol})$ & $\mathrm{CH}_{3} \mathrm{CN}$ & 25 & 8 & $58^{e}$ & 56 \\
\hline 3 & $\mathrm{Si}-\mathrm{Co}$ & $\mathrm{H}_{2} \mathrm{O}_{2}(25 \mathrm{mmol})$ & $\mathrm{CH}_{3} \mathrm{CN}$ & 25 & 8 & 62 & 62 \\
\hline 4 & Si-Co & $\mathrm{H}_{2} \mathrm{O}_{2}(10 \mathrm{mmol})$ & $\mathrm{CH}_{3} \mathrm{CN}$ & 55 & 8 & $78^{e}$ & 77 \\
\hline 5 & $\mathrm{Si}-\mathrm{Co}$ & $\mathrm{H}_{2} \mathrm{O}_{2}(10 \mathrm{mmol})$ & $\mathrm{CH}_{3} \mathrm{CN}$ & 80 & 6 & 100 & 100 \\
\hline 6 & None & $\mathrm{H}_{2} \mathrm{O}_{2}(10 \mathrm{mmol})$ & $\mathrm{CH}_{3} \mathrm{CN}$ & 25 & 8 & 10 & $\mathrm{f}$ \\
\hline 7 & None & $\mathrm{H}_{2} \mathrm{O}_{2}(10 \mathrm{mmol})$ & $\mathrm{CH}_{3} \mathrm{CN}$ & 80 & 8 & 60 & $\mathrm{f}$ \\
\hline 8 & $\mathrm{Si}^{\mathrm{d}}+\mathrm{CoCl}_{2}$ & $\mathrm{H}_{2} \mathrm{O}_{2}(10 \mathrm{mmol})$ & $\mathrm{CH}_{3} \mathrm{CN}$ & 25 & 8 & 9 & 9 \\
\hline 9 & Si-Co & TBHP $(10 \mathrm{mmol})$ & $\mathrm{CH}_{3} \mathrm{CN}$ & 25 & 8 & 0 & 0 \\
\hline 10 & Si-Co & $\mathrm{H}_{2} \mathrm{O}_{2}(10 \mathrm{mmol})$ & $\mathrm{CH}_{3} \mathrm{OH}$ & 25 & 8 & 9 & e \\
\hline 11 & Si-Co & $\mathrm{H}_{2} \mathrm{O}_{2}(10 \mathrm{mmol})$ & Acetone & 25 & 8 & 5 & 5 \\
\hline 12 & Si-Co & $\mathrm{H}_{2} \mathrm{O}_{2}(10 \mathrm{mmol})$ & THF & 55 & 8 & 24 & 24 \\
\hline 13 & $\mathrm{Si}-\mathrm{Co}$ & $\mathrm{H}_{2} \mathrm{O}_{2}(10 \mathrm{mmol})$ & $\mathrm{H}_{2} \mathrm{O}$ & 55 & 8 & 53 & 53 \\
\hline 14 & $\mathrm{Si}-\mathrm{Co}$ & $\mathrm{H}_{2} \mathrm{O}_{2}(10 \mathrm{mmol})$ & $\mathrm{H}_{2} \mathrm{O}$ & 80 & 8 & 65 & 65 \\
\hline 15 & $\mathrm{Si}-\mathrm{Co}$ & $\mathrm{H}_{2} \mathrm{O}_{2}(10 \mathrm{mmol})$ & $\mathrm{H}_{2} \mathrm{O}$ & 100 & 8 & 100 & $97^{g}$ \\
\hline
\end{tabular}

a Reaction conditions: aniline ( $5 \mathrm{mmol})$, catalyst $(5 \mathrm{mg})$ and solvent $(1 \mathrm{~mL})$.

b Determined by GC analysis.

c Amount of azoxybenzene based on NMR yields.

d SBA-15 silica ( $5 \mathrm{mg})$ and $\mathrm{CoCl}_{2} \cdot 2 \mathrm{H}_{2} \mathrm{O}(0.3 \mathrm{mg})$ in water $(2 \mathrm{~mL})$ were mixed and the solvent was removed under vacuum. The residue was used as the catalyst.

e Trace of azobenzene.

f A mixture of various products including $\mathrm{PhN}=\mathrm{NPh}$ and $\mathrm{PhNHOH}$, but major for azobenzene.

g Azobenzene (3\%) was obtained.

Table 2

Formation of azoxybenzenes via oxidation of anilines ${ }^{\mathrm{a}}$

\begin{tabular}{|c|c|c|c|}
\hline Entry & Anilines & Products & Yield (\%) \\
\hline 1 & p-Phenylenediamine & Polymer & - \\
\hline 2 & 4-t-Butyianiline & & 98 \\
\hline 3 & 4-Methoxyaniline & & 86 \\
\hline 4 & 2,4,6-Trimethylaniline & & 92 \\
\hline 5 & 4-Bromoaniline & & 71 \\
\hline 6 & 4-Nitroaniline & & 59 \\
\hline 7 & 1-Aminonaphathalene & & 67 \\
\hline 8 & 2,6-Diisopropylaniline & No react & - \\
\hline
\end{tabular}

a Reaction conditions: aniline compound (5 mmol), $\mathrm{H}_{2} \mathrm{O}_{2}(10 \mathrm{mmol})$ and $\mathrm{Si}-\mathrm{Co}(5 \mathrm{mg})$ in $\mathrm{CH}_{3} \mathrm{CN}$ at $80^{\circ} \mathrm{C}$.

\section{Experimental}

\subsection{General}

All reaction steps for polymerization were performed under a dry nitrogen atmosphere. Dichoromethane was dried with $\mathrm{CaH}_{2}$ and distilled under nitrogen. $\left[\mathrm{CH}_{3}\left(\mathrm{OCH}_{2} \mathrm{CH}_{2}\right)_{n} \mathrm{OTs}\right](\mathbf{1})$ and $\mathrm{N}\left[\mathrm{CH}_{2} \mathrm{CH}_{2} \mathrm{~N}\left(\mathrm{CH}_{3}\right)_{2}\right]_{3}$ (Metren) were prepared according to the method reported in the literature [11]. Nuclear magnetic resonance spectra were recorded in $\mathrm{CDCl}_{3}$ on a Bruker AM-300 spectrometer. Infrared spectra were measured on a Nicolet Magna-IR 550 spectrometer (Series-II) as $\mathrm{KBr}$ pallets. Gel permeation chromatography (GPC) data were obtained from a Waters Model 590 liquid chromatograph installed with a Lab Allience RI 2000 detector using THF as eluant (at the rate $1 \mathrm{~mL} / \mathrm{min}$ ) at $40^{\circ} \mathrm{C}$ and polystyrene calibration curve for analyses. 


\subsection{Synthesis and characterization}

\subsubsection{Preparation of macro-initiator (2)}

To a mixture of tosylate $\mathbf{1}(21.35 \mathrm{~g}, 10 \mathrm{mmol})$ and sodium azide $(2.6 \mathrm{~g}, 40 \mathrm{mmol})$ in a flask was added acetone $(600 \mathrm{~mL})$. The resulting mixture was heated to reflux for $24 \mathrm{~h}$. Upon filtration off the salt, the azido compound was obtained $(18.1 \mathrm{~g}, 88 \%):{ }^{1} \mathrm{H}$ $\operatorname{NMR}\left(\mathrm{CDCl}_{3}\right) \delta 3.61\left(176 \mathrm{H}, \mathrm{s},-\mathrm{OCH}_{2} \mathrm{CH}_{2} \mathrm{O}-\right), 3.52(2 \mathrm{H}, \mathrm{t}, J=5 \mathrm{~Hz}$, $\left.-\mathrm{OCH}_{2} \mathrm{CH}_{2} \mathrm{~N}_{3}\right), 3.38\left(2 \mathrm{H}, \mathrm{t}, J=5 \mathrm{~Hz},-\mathrm{OCH}_{2} \mathrm{CH}_{2} \mathrm{~N}_{3}\right), 3.35(3 \mathrm{H}, \mathrm{s}$, $-\mathrm{OCH}_{3}$ ).

The reaction of the obtained azide $(20.4 \mathrm{~g}, 10 \mathrm{mmol})$ and hydrogen gas (200 psi in a $500-\mathrm{mL}$ autoclave) on Pd/C $(200 \mathrm{mg})$ in $150 \mathrm{~mL}$ of ethanol produced the corresponding amine ( $18.0 \mathrm{~g}, 89 \%) .{ }^{1} \mathrm{H}$ NMR $\delta 3.61\left(176 \mathrm{H}, \mathrm{s},-\mathrm{OCH}_{2} \mathrm{CH}_{2} \mathrm{O}-\right), 3.48\left(2 \mathrm{H}, \mathrm{t}, J=6 \mathrm{~Hz},-\mathrm{OCH}_{2} \mathrm{CH}_{2} \mathrm{~N}-\right)$, $3.35\left(3 \mathrm{H}, \mathrm{s},-\mathrm{OCH}_{3}\right), 2.83\left(2 \mathrm{H}, \mathrm{t}, J=6 \mathrm{~Hz},-\mathrm{OCH}_{2} \mathrm{CH}_{2} \mathrm{~N}-\right)$.

2-Bromoisobutyryl bromide ( $1.36 \mathrm{~mL}, 11 \mathrm{mmol}$ ) was added into a mixture of the amine compound $(20.24 \mathrm{~g})$ and triethylamine $(10 \mathrm{~mL})$ in anhydrous $\mathrm{CH}_{2} \mathrm{Cl}_{2}(150 \mathrm{~mL})$ with stirring at $0^{\circ} \mathrm{C}$. Upon addition, the mixture was further stirred at room temperature for $6 \mathrm{~h}$. Water $(100 \mathrm{~mL})$ was then added and the organic layer was separated. After concentration, the residue was washed with ice-cooled ether $(3 \times 100 \mathrm{~mL})$ and the desired compound 2 was obtained as white solids (17.7, 82\%). ${ }^{1} \mathrm{H}$ NMR $\delta 3.61\left(176 \mathrm{H}, \mathrm{s},-\mathrm{OCH}_{2} \mathrm{CH}_{2} \mathrm{O}-\right), 3.52$ $\left(2 \mathrm{H}, \mathrm{t}, J=6 \mathrm{~Hz},-\mathrm{OCH}_{2} \mathrm{CH}_{2} \mathrm{~N}-\right), 3.38\left(2 \mathrm{H}, \mathrm{t}, J=6 \mathrm{~Hz},-\mathrm{OCH}_{2} \mathrm{CH}_{2} \mathrm{~N}-\right)$, $3.35(3 \mathrm{H}, \mathrm{s}), 1.92\left(6 \mathrm{H}, \mathrm{s},-\mathrm{C}\left(\mathrm{CH}_{3}\right)_{2}\right)$.

\subsubsection{Diblock copolymer (EO-MA)}

A mixture of $2(2.1 \mathrm{~g})$ and $\mathrm{CuBr}(28.6 \mathrm{mg})$ was placed in a flask sealed with a septum. The flask was evacuated and flashed with nitrogen three times. Methyl acrylate $(7.2 \mathrm{~mL}, 80 \mathrm{mmol})$ was syringed into the above mixture with stirring. Metren $(56 \mu \mathrm{L}$, $0.2 \mathrm{mmol}$ ) was then added and the polymerization took place immediately. After stirring $10 \mathrm{~min}$, the reaction was quenched by the addition of THF $(30 \mathrm{~mL})$. The reaction mixture was filtered through silica gel to remove the catalyst. Upon concentration and re-precipitation in ether/methanol, the obtained copolymer was dried under vacuum overnight $(3.5 \mathrm{~g}) .{ }^{1} \mathrm{H} \mathrm{NMR}\left(\mathrm{CDCl}_{3}\right) \delta 3.64-3.60$ $(296 \mathrm{H}, \mathrm{br}), 3.37\left(3 \mathrm{H}, \mathrm{s},-\mathrm{OCH}_{3}\right), 2.29(40 \mathrm{H}, \mathrm{br}), 2.00-1.30(80 \mathrm{H}$, br), $1.14\left(3 \mathrm{H}, \mathrm{s},-\mathrm{C}\left(\mathrm{CH}_{3}\right)_{2}\right), 1.12\left(3 \mathrm{H}, \mathrm{s},-\mathrm{C}\left(\mathrm{CH}_{3}\right)_{2}\right) . \mathrm{GPC}: M_{\mathrm{N}}=4500$, $\mathrm{PDI}=1.14$

\subsubsection{Modification of copolymer (EO-MA-N)}

A mixture of EO-MA $(2.0 \mathrm{~g})$ and $\mathrm{NH}_{2}\left(\mathrm{CH}_{2}\right)_{3} \mathrm{~N}_{3}(5 \mathrm{~mL})$ was heated to $100{ }^{\circ} \mathrm{C}$ for $10 \mathrm{~h}$. Excess of azide was removed under vacuum and the residue was dissolved in $\mathrm{CH}_{2} \mathrm{Cl}_{2}$. Addition of hexane gave the desired product as white precipitates $(2.6 \mathrm{~g})$.

This solid $(2.0 \mathrm{~g})$ dissolved in dried THF $(10 \mathrm{~mL})$ was slowly added to a solution of $\mathrm{PPh}_{3}(1.31 \mathrm{~g})$ in THF $(10 \mathrm{~mL})$. The resulting mixture was stirred at room temperature for $10 \mathrm{~h}$. Then water $(10 \mathrm{~mL})$ was added. The mixture was heated to reflux for $1 \mathrm{~h}$. After cooling, the organic layer was separated and washed with brine. The crude product was washed with ether $(3 \times 50 \mathrm{~mL})$ to give EO-MA$\mathrm{N}$ as white solids $(1.45 \mathrm{~g}) .{ }^{1} \mathrm{H}$ NMR $\left(\mathrm{CDCl}_{3}\right) \delta 3.70-3.60(296 \mathrm{H}, \mathrm{br})$, $3.40\left(3 \mathrm{H},-\mathrm{OCH}_{3}\right), 3.33\left(2 \mathrm{H}, \mathrm{CH}_{2}-\mathrm{N}\right), 2.88\left(2 \mathrm{H},-\mathrm{NH}-\mathrm{CH}_{2}\right), 2.40-1.30$ $\left(122 \mathrm{H},-\mathrm{CHCH}_{2}-\right), 1.14-1.12\left(6 \mathrm{H},-\mathrm{C}\left(\mathrm{CH}_{3}\right)_{2}\right)$. FTIR $v\left(\mathrm{~cm}^{-1}\right)(\mathrm{KBr})$ : 3423 (br, N-H), 1746 (vs, C=O), 1673 (vs, CONH).

\subsubsection{Cobalt-containing mesoporous silicas ( $\mathrm{Si}-\mathrm{Co})$}

A mixture of EO-MA-N $(0.5 \mathrm{~g}), \mathrm{CoCl}_{2}(0.12 \mathrm{~g}), 37 \% \mathrm{HCl}(6.0 \mathrm{~g})$, and $\mathrm{Si}(\mathrm{OEt})_{4}(1.5 \mathrm{~g})$ in water $(25 \mathrm{~g})$ was stirred at room temperature for $24 \mathrm{~h}$. The obtained mesoporous silicas in $50.0 \mathrm{~g}$ water was hydrothermally treated at $100^{\circ} \mathrm{C}$ for $24 \mathrm{~h}$. The organic templates were removed by calcinations at $560^{\circ} \mathrm{C}$ for $6 \mathrm{~h}$ under air, which allowed the cobalt complex to form the metal oxide.

\subsubsection{Characterization of Si-Co}

The powder X-ray diffraction patterns (XRD) were taken on a Scintag X1 instrument $(\lambda=0.1326 \mathrm{~nm})$. The TEM images of mesoporous silicas were recorded on a Hitachi S-7100 transmission electron microscope (TEM) with an operating voltage of $75 \mathrm{keV}$. The $\mathrm{N}_{2}$ adsorption-desorption isotherms were obtained at $77 \mathrm{~K}$ on a Micromeritics ASAP 2010 apparatus, and the pore size distribution was calculated from the adsorption isotherms using the Barrett-Joyner-Halenda (BJH) method.

\subsection{Catalysis}

A mixture of substrate ( $5 \mathrm{mmol}), \mathrm{H}_{2} \mathrm{O}_{2}$ (37\%, $10 \mathrm{mmol}$ ), solvent $(1 \mathrm{~mL})$ and Si-Co $(5 \mathrm{mg})$ was placed in a $20-\mathrm{mL}$ flask. The solution was stirred at a certain temperature. Upon standing for $1 \mathrm{~h}$, the organic product was separated from the reaction mixture by extraction with dichloromethane $(2 \times 2 \mathrm{~mL})$. The combined organic portions was dried and concentrated. Product analysis was performed by GC and ${ }^{1} \mathrm{H}$ NMR spectroscopic methods, which were all essentially identical to those reported in the literature.

\subsection{1. ${ }^{1} \mathrm{H}$ NMR data of products}

3.3.1.1. Aazoxybenzene. ${ }^{1} \mathrm{H} \mathrm{NMR}\left(300 \mathrm{MHz}, \mathrm{CDCl}_{3}\right) \delta 7.36-7.85(5 \mathrm{H}$, $\mathrm{m}, \mathrm{Ar}-\mathrm{H}), 8.14-8.29(5 \mathrm{H}, \mathrm{m}, \mathrm{Ar}-\mathrm{H})[10 \mathrm{~b}]$.

3.3.1.2. 4,4'-Di-t-butylazoxybenzene. ${ }^{1} \mathrm{H}$ NMR $\left(300 \mathrm{MHz}, \mathrm{CDCl}_{3}\right)$ $\delta 1.34(9 \mathrm{H}, \mathrm{s}), 1.35(9 \mathrm{H}, \mathrm{s}), \quad 7.20-7.40(4 \mathrm{H}, \mathrm{m}), \quad 7.90-8.21$ $(4 \mathrm{H}, \mathrm{m})[15]$.

3.3.1.3. 4,4'-Dimethoxyazoxybenzene. ${ }^{1} \mathrm{H}$ NMR $\left(300 \mathrm{MHz}, \mathrm{CDCl}_{3}\right) \delta$ 3.85 (6H, s, OMe), 7.0-7.2 (4H, m), 8.15-8.23 (4H, m) [10b].

3.3.1.4. Azoxymesitylene. ${ }^{1} \mathrm{H}$ NMR $\left(300 \mathrm{MHz}, \mathrm{CDCl}_{3}\right) \delta 2.18(6 \mathrm{H}, \mathrm{s})$, $2.29(3 \mathrm{H}, \mathrm{s}), 2.35(3 \mathrm{H}, \mathrm{s}), 2.37(6 \mathrm{H}, \mathrm{s}), 6.81(2 \mathrm{H}, \mathrm{s}), 6.90(2 \mathrm{H}, \mathrm{s})[16]$.

3.3.1.5. 4,4'-Dibromoazoxybenzene. ${ }^{1} \mathrm{H}$ NMR (300 MHz, $\left.\mathrm{CDCl}_{3}\right) \delta$ $7.51(2 \mathrm{H}, \mathrm{d}, J=6 \mathrm{~Hz}), 7.71(2 \mathrm{H}, \mathrm{d}, J=6 \mathrm{~Hz}), 8.12(2 \mathrm{H}, \mathrm{d}, J=6 \mathrm{~Hz}), 8.32$ $(2 \mathrm{H}, \mathrm{d}, J=6 \mathrm{~Hz})[10 \mathrm{~b}]$.

3.3.1.6. 4,4'-Dinitroazoxybenzene. ${ }^{1} \mathrm{H}$ NMR $\left(300 \mathrm{MHz}, \mathrm{CDCl}_{3}\right) \delta 8.35$ $(4 \mathrm{H}, \mathrm{br}), 8.57(4 \mathrm{H}, \mathrm{br})[10 \mathrm{~b}]$.

3.3.1.7. 1,1'-Aazoxynaphthalene. ${ }^{1} \mathrm{H}$ NMR $\left(300 \mathrm{MHz}, \mathrm{CDCl}_{3}\right) \delta 7.45$ $(6 \mathrm{H}, \mathrm{m}), 7.89(5 \mathrm{H}, \mathrm{m}), 8.28(1 \mathrm{H}, \mathrm{m}), 8.61(1 \mathrm{H}, \mathrm{m}), 9.2(1 \mathrm{H}, \mathrm{m})[10 \mathrm{~b}]$.

\section{Acknowledgment}

We thank the National Science Council, Taiwan, ROC for the financial support (NSC-96-2113-M002-009).

\section{References}

[1] (a) E. Buncel, Can. J. Chem. 78 (2000) 1251;

(b) A. Albini, E. Fasani, M. Moroni, S. Pietra, J. Org. Chem. 51 (1986) 88;

(c) M. Ghedini, D. Pucci, A. Vinuales, Mol. Cryst. Liq. Cryst. 465 (2007) 59

(d) M. Cifelli, G. Cinacchi, L. De Gaetani, J. Chem. Phys. 125 (2006) 164912/1, and references therein.

[2] E. Buncel, Acc. Chem. Res. 6 (1975) 132.

[3] (a) R.W. Murray, K. Iyanar, J. Chen, J.T. Wearing, Tetrahedron Lett. 37 (1996) 805; (b) G. Barak, Y. Sasson, J. Org. Chem. 54 (1989) 3484.

[4] R.W. Murray, R. Jeyaraman, L. Mohan, Tetrahedron Lett. 27 (1986) 2335

[5] A. McKillop, J.A. Tarbin, Tetrahedron 43 (1987) 1753.

[6] (a) L. Badger, J. Chem. Soc. (1953) 2147; (b) F. Alonso, G. Radivoy, M. Yus, Tetrahedron 56 (2000) 8673.

[7] H.-U. Blaser, Science 313 (2006) 312.

[8] K. Neimann, R. Neumann, Chem. Commun. (2001) 487

[9] D. Sloboda-Rozner, P. Witte, P.L. Alsters, R. Neumann, Adv. Synth. Catal. 346 (2004) 339. 
[10] (a) H.R. Sonawane, A.V. Pol, P.P. Moghe, S.S. Biswas, A. Sudalai, J. Chem. Soc., Chem. Commun. (1994) 1215;

(b) S. Suresh, R. Joseph, B. Jayachandran, A.V. Poi, M.P. Vinod, A. Sudalai, H.R. Sonawane, T. Ravindranathan, Tetrahedron 51 (1995) 11305.

[11] I.-S. Ke, S.-T. Liu, Appl. Catal. A: Gen. 317 (2007) 91.

[12] J. Pyun, K. Matyjaszewski, Chem. Rev. 101 (2001) 2921.
[13] C.Y. Liu, D.Y. Chen, M.C. Cheng, S.-M. Peng, S.-T. Liu, Organometallics 14 (1995) 1983.

[14] M.H. Kim, K.-H. Choo, Catal. Commun. 8 (2007) 462.

[15] I. Shimao, S. Matsumura, Bull. Chem. Soc. Jpn. 49 (1976) 2294

[16] R.A. Cox, E. Brucel, Can. J. Chem. 51 (1973) 3143. 